\title{
The Influence of Phosphate Mining on the Chemical Composition of Annual Atmospheric Deposition in Catalão (GO) and Tapira (MG), Brazil
}

\author{
Fabiano Tomazini da Conceição • Taise Litholdo • Diego de Souza Sardinha • \\ Rodrigo Braga Moruzzi • Guillermo Rafael Beltran Navarro • Letícia Hirata Godoy
}

Received: 8 January 2015 / Accepted: 7 May 2015 /Published online: 4 February 2016

(C) Springer International Publishing Switzerland 2016

\begin{abstract}
Brazil is an important country within the global mineral industry. The main reserves of phosphate rock in Brazil are contained in the states of Goiás and Minas Gerais, at the Catalão and Tapira cities, respectively. Atmospheric inputs due to the mining of phosphate rock may have various effects on human health in areas near these types of mines. Thus, this work evaluated the influence of phosphate mining on the chemical composition and annual atmospheric deposition in Catalão (GO) and Tapira (MG), Brazil. The pH of rainwater was 6.90 in Catalão and 6.80 in Tapira. The ionic concentrations (in $\mu \mathrm{eq} / \mathrm{L}$ ) at both study sites decreased in the following order: $\mathrm{Ca}^{2+}>\mathrm{Na}^{+}>\mathrm{Mg}^{2+}>\mathrm{K}^{+}$ for cations and $\mathrm{HCO}_{3}{ }^{-}>\mathrm{NO}_{3}{ }^{-}>\mathrm{SO}_{4}{ }^{2-}>\mathrm{PO}_{4}{ }^{3-}>\mathrm{F}^{-}>\mathrm{Cl}^{-}$ for anions. High $\mathrm{Ca}^{2+}$ content indicates that $\mathrm{Ca}^{2+}$ contributes to the neutralisation of the rainwater $\mathrm{pH}$ in both of the areas studied. The annual atmospheric deposition
\end{abstract}

Capsule abstract The high $\mathrm{Ca}^{2+}$ content neutralises the $\mathrm{pH}$ of rainwater, with $\mathrm{NO}_{3}{ }^{-}, \mathrm{SO}_{4}{ }^{2-}, \mathrm{PO}_{4}{ }^{3-}$ and $\mathrm{F}^{-}$attributed to phosphate mining activities.

F. T. da Conceição • T. Litholdo • R. B. Moruzzi •

G. R. B. Navarro $\cdot$ L. H. Godoy

UNESP — Instituto de Geociências e Ciências Exatas (IGCE),

Rio Claro, SP, Brazil

D. de Souza Sardinha

UNIFAL - Universidade Federal de Alfenas, Instituto de

Ciência e Tecnologia, Poços de Caldas, MG, Brazil

F. T. da Conceição $(\triangle)$

Avenida 24-A, n. 1515, CEP 13506-900 Bela Vista, Rio

Claro, São Paulo, Brazil

e-mail: ftomazini@sorocaba.unesp.br of $\mathrm{NO}_{3}{ }^{-}$and $\mathrm{SO}_{4}{ }^{2-}$ can be attributed to the use of dieselpowered trucks in and around mining areas. Soil dust derived is responsible for the annual atmospheric deposition of $\mathrm{Na}^{+}$and $\mathrm{K}^{+}$. Phosphate mining activities are the main source of the annual atmospheric deposition of $\mathrm{PO}_{4}{ }^{3-}$ and $\mathrm{F}^{-}$.

Keywords Rainwater composition · Atmospheric environment $\cdot$ Mining activities $\cdot$ Brazil

\section{Introduction}

The aerosols and gases are removed from the atmosphere by rainout (condensation processes within clouds) or washout (impaction with falling raindrops below clouds) (Berner and Berner 1996). The evaporation and precipitation can be used to purify water in some contexts, but these processes can also introduce many substances arising from air pollution into the hydrologic cycle (Keene et al. 1986). The dissolved components in rainwater can be divided into three groups: (a) those derived from sea salt aerosols, (b) those derived from terrestrial aerosols and (c) those derived from anthropogenic sources (Négrel and Roy 1998).

Many human activities are potential sources of element/compounds emissions to the atmosphere, such as the burning of fossil fuels, industrial emissions, waste incineration, agriculture and mining, placing these pollutants locally or transporting them for long distances (Molinaroli et al. 1999). Few studies have documented 
the variation in chemical composition of the rainwater in south and southeast Brazil (Forti et al. 1990; Danelon and Moreira-Nordemann 1991; Gonçalves et al. 2000; Lara et al. 2001; Mello 2001; Rocha et al. 2003; Conceição and Bonotto 2004; Leal et al. 2004; Mello and de Almeida 2004; Migliavacca et al. 2004, 2005; Fornaro and Gutz 2006; Pelicho et al. 2006; Fontenele et al. 2009; Conceição et al. 2010, 2011).

Brazilian mining activities are responsible, directly and indirectly, for the employment of more than 198,000 people, with a mineral production of US\$ 14 billion in the first semester of 2014, making Brazil an important contributor to global mineral production (DNPM 2014). Brazil is the largest global producer of niobium, the second-largest producer of iron and manganese and the third-largest producer of aluminium. However, Brazil still depends heavily on imports of some strategic minerals, including phosphates, which are important raw materials in fertiliser production. Brazil currently produces only $2 \%$ of its domestic consumption of phosphates. The total global reserves of phosphate rock are 35.5 billion tonnes, of which Morocco ( 21 billion), the United States (4.2 billion) and South Africa (2.5 billion) represent $78 \%$ of the total. The global production of phosphate was estimated to be 150 million tonnes in 2011, with the United States (41.5 million tonnes), Morocco (24 million tonnes) and China (20 million tonnes) being the highest-producing countries (DNPM 2011).

The main reserves of phosphate rock in Brazil are located in Catalão, Goiás and Tapira, Minas Gerais (DNPM 2012). The alkaline rocks in Catalão and Tapira are used as a raw material in the production of phosphate fertilisers and their industrial by-products. Industrial processing of these alkaline rocks begins with a flotation-separation process in which apatites $\left(\mathrm{Ca}_{5}\left(\mathrm{PO}_{4}\right)_{3} \mathrm{~F}\right)$ are concentrated. These apatites are dissolved by $\mathrm{H}_{2} \mathrm{SO}_{4}$ to produce SSP (simple superphosphate) and $\mathrm{H}_{3} \mathrm{PO}_{4}$, creating $\mathrm{H}_{2} \mathrm{SiF}_{6}$ and phosphogypsum as by-products. The TSP (triple superphosphate) is obtained by mixing the concentrated phosphate with $\mathrm{H}_{3} \mathrm{PO}_{4}$. MAP (monoammonium phosphate) and DAP (diammonium phosphate) are created by mixing $\mathrm{H}_{3} \mathrm{PO}_{4}$ with ammonium. The process by which Brazilian plants produce phosphate fertilisers and by-products is described in detail by Conceição and Bonotto (2006) and Saueia and Mazzilli (2006).

Elements/compounds emitted to the atmosphere by phosphate rock mining may impact human health near these mines, as atmospheric pollutants can be washed out by rainwater. Thus, the main aim of this work is to evaluate the extent of atmospheric pollution from mining activities by examining the chemical composition of rainwater and the annual atmospheric deposition in phosphate mining areas. This study focuses on the municipalities of Catalão (GO) and Tapira (MG), which are where the main Brazilian reserves of phosphate rock are located. The results presented herein elucidate how anthropogenic activities may affect the atmospheric system around areas of phosphate mining, thus providing important contributions for public actions.

\section{Overview of the Study Areas}

The Alto Parnaíba Igneous Province (APIP, Fig. 1) in the southeast of Goiás (Catalão I and Catalão II) and southwestern Minas Gerais (Serra Negra, I Salitre I, Salitre II, Araxá and Tapira) comprises kamafugites, kimberlites, lamproites and alkaline-carbonatite complexes. These minerals are the result of magmatism related to the activity of the Trindade Mantle Plume that affected the Brazilian platform the end of the Jurassic and Lower Tertiary beginning with the basalt flows of the Paraná Basin (Gibson et al. 1995).

The main rock units recognised in the Catalão and Tapira alkaline complexes are dunites, pyroxenites, phoscorites, phlogopitites and carbonatites. These complexes have been weathered since the Tertiary Period, resulting in the formation of a thick lateritic cover extending to a depth of about $100 \mathrm{~m}$ and enriched in $\mathrm{P}$ (apatite), $\mathrm{Nb}$ (pyrochlore) and $\mathrm{Ti}$ (ilmenite, perovskite, anatase, rutile and titanite) (Oliveira and Imbernon 1998). Minerals containing REE are also present in Catalão.

Mining activities in the alkaline rocks of Catalão and Tapira have a production capacity of approximately 1,900,000 tonnes/year of concentrated phosphate $\left(35.5 \% \mathrm{P}_{2} \mathrm{O}_{5}\right)$ from ore that contains $12 \% \mathrm{P}_{2} \mathrm{O}_{5}$. This mineral deposit contains 992 million tonnes of phosphate rock, which is $40 \%$ of the phosphate reserves in Brazil (DNPM 2011). These mining complexes cover $26,039,000 \mathrm{~m}^{2}$ in Catalão and 78,403,000 $\mathrm{m}^{2}$ in Tapira, including open air mines and support facilities.

The climate of the area of these complexes is type Aw, i.e. tropical rainy climate, with wet summer and dry winter. The average monthly temperature is above $18^{\circ} \mathrm{C}$ for most of the year. The average temperature of the 


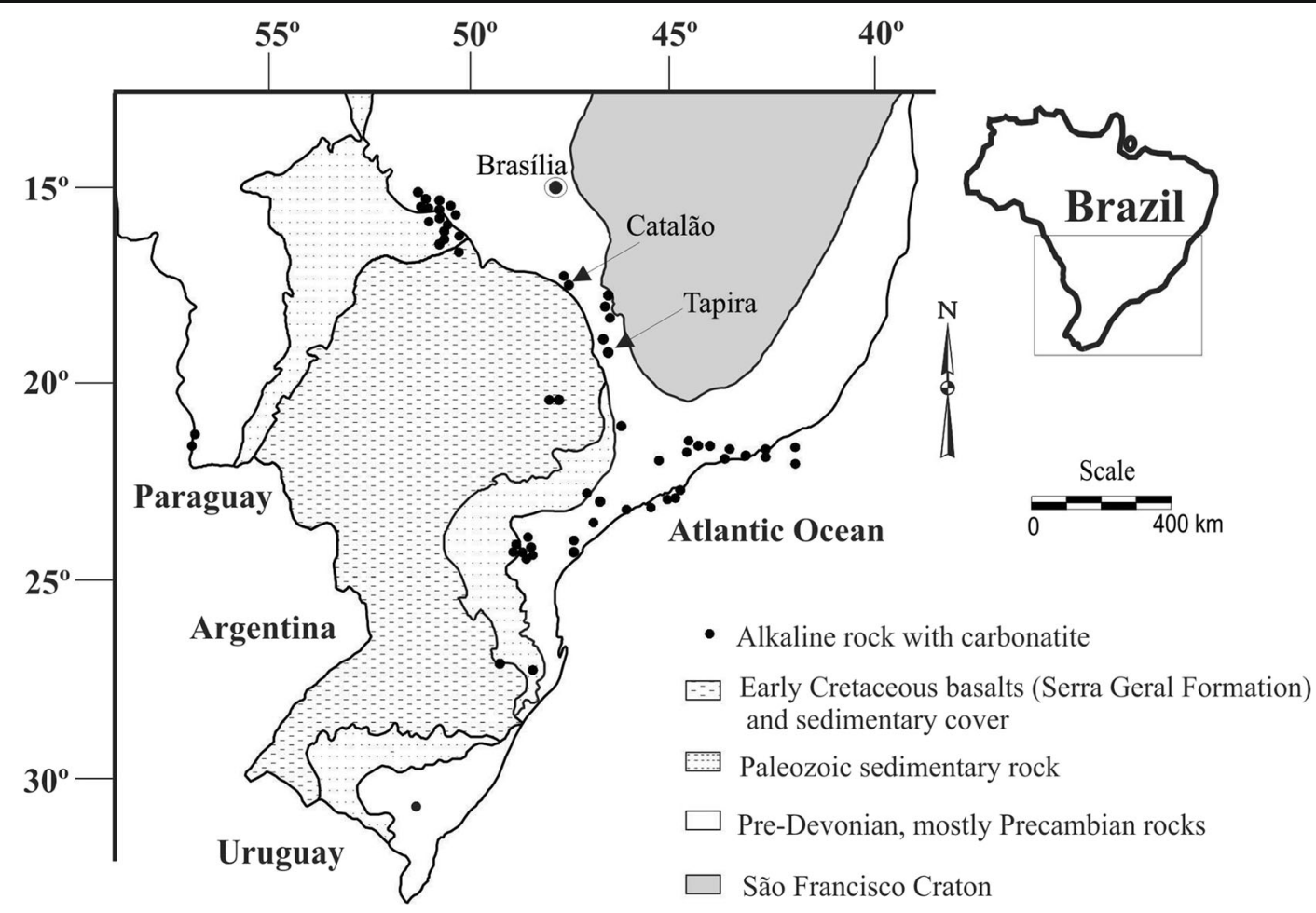

Fig. 1 Distribution of alkaline-cabonatites complexes in Brazil together with the location of Catalão and Tapira phosphate mining (modified from Ulbrich and Gomes, 1981)

warmest month exceeds $22{ }^{\circ} \mathrm{C}$, while the precipitation of the rainiest month is ten times higher than that of the driest month. The relative humidity in both Catalão and Tapira is approximately $78 \%$ during the rainiest months and $50 \%$ during August and September, the months with the lowest average relative humidity.

The average annual rainfall between 1987 and 2007 was $1407 \mathrm{~mm}$ in Catalão and $1614 \mathrm{~mm}$ in Tapira. The average monthly rainfall between 1987 and 2007 is shown in Fig. 3, which illustrates that the months of July and January had the lowest and highest average precipitation, respectively, in both areas. The total precipitation in 2007 was $1542 \mathrm{~mm}$ in Catalão and $1430 \mathrm{~mm}$ in Tapira. The annual rainfall is distributed in a tropical pattern with two well-defined seasons: April to September is the dry season, with average rainfall between 3 and $65 \mathrm{~mm}$ in Catalão and 14 and 140 in Tapira, whereas October to March is the wet season, with average rainfall between 108 and $280 \mathrm{~mm}$ in Catalão and 119 and $310 \mathrm{~mm}$ in Tapira. The rainiest and driest years during this period were 1991 (1677 mm) and $1966(1050 \mathrm{~mm})$ in Catalão and $2003(2211 \mathrm{~mm})$ and $1999(953 \mathrm{~mm})$ in Tapira.

The frequency distribution for precipitation values with $5,20,50,80$ and $95 \%$ occurrence probability based on the historical data from 1987 to 2007 is shown in Fig. 2. The precipitation amounts with a $5 \%$ occurrence probability, corresponding to a 20 -year recurrence period (TR), in the months of January, June and December are 420, 33 and $421 \mathrm{~mm}$ in Catalão and 564, 37 and $388 \mathrm{~mm}$ in Tapira, respectively. In contrast, the precipitation amounts with a $95 \%$ occurrence probability (corresponding to a TR of 1 year) in the months of January, June and December are 72, <1 and $132 \mathrm{~mm}$ in Catalão and 124, <1 and $114 \mathrm{~mm}$ in Tapira, respectively. Thus, despite the observed variations in precipitation during 2007, this year likely represented the majority of the precipitation values with occurrence probability between 20 and $80 \%$ (5- and 1.25-year TR, respectively), and thus near to the historical precipitation average in both studied areas.

Both Catalão and Tapira are located within the drainage basin of the La Plata River, a tributary of the Paraná River. The regional drainage network is dendritic, with a slight tendency for the larger elements of the drainage network to be oriented along a SW/NE axis. The default location of this drainage area has the ring radially. The drainage system into the dome is controlled by faults. The average monthly discharge from these alkaline complexes between 2005 and 2007 was $0.24 \mathrm{~m}^{3} / \mathrm{s}$ in 


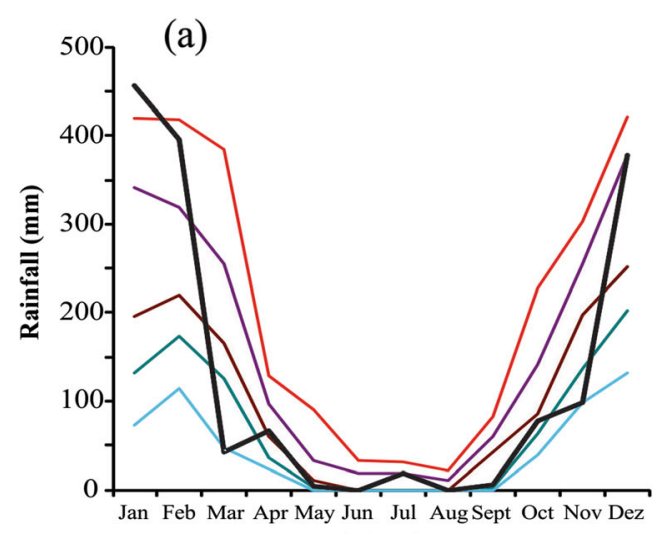

Month

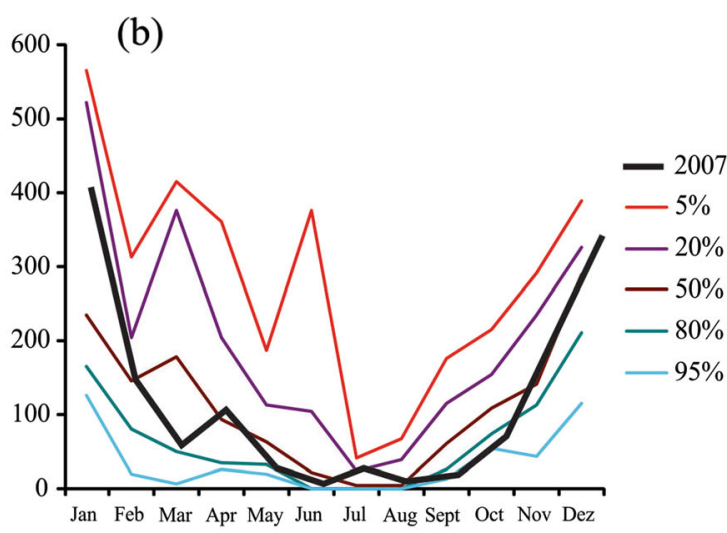

Month

Fig. 2 Frequency distribution for precipitation values

Catalão and $0.26 \mathrm{~m}^{3} / \mathrm{s}$ in Tapira, with the maximum and minimum values recorded in December and in July/August, respectively. The average monthly discharge between 2005 and 2007 is shown in Fig. 3.

\section{Materials and Methods}

\subsection{Sampling}

The evaluation of the chemical composition of rainwater and the annual atmospheric deposition was made at two sampling points, one in the Catalão complex and other in the Tapira complex (Fig. 1). The sampling locations were chosen due to their distance from pollution sources, the prevailing wind direction and logistical reasons. Forty total deposition samples were collected in each sampling point between January and December 2007, during both the humid and dry seasons. Each sample corresponded to a single precipitation event from which at least $500 \mathrm{~mL}$ could be captured, that amount being the minimum necessary to carry out all chemical analyses. Rainwater samples were transferred and stored in 500-mL polyethylene bottles less than $12 \mathrm{~h}$ after the conclusion of each precipitation event. Samples were also collected from one bulk collector consisting of a 22 -cm-diameter polyethylene funnel attached to a 2-L polyethylene container fixed $2 \mathrm{~m}$ above the soil. The funnel was covered with nylon mesh to avoid contamination from leaves, insects, or other material. After each sampling event, the collector was washed two or three times with distilled and deionised water. The volume of rain collected in the sample was recorded and used to calculate
Fig. 3 Average monthly discharge between 2005 and 2007

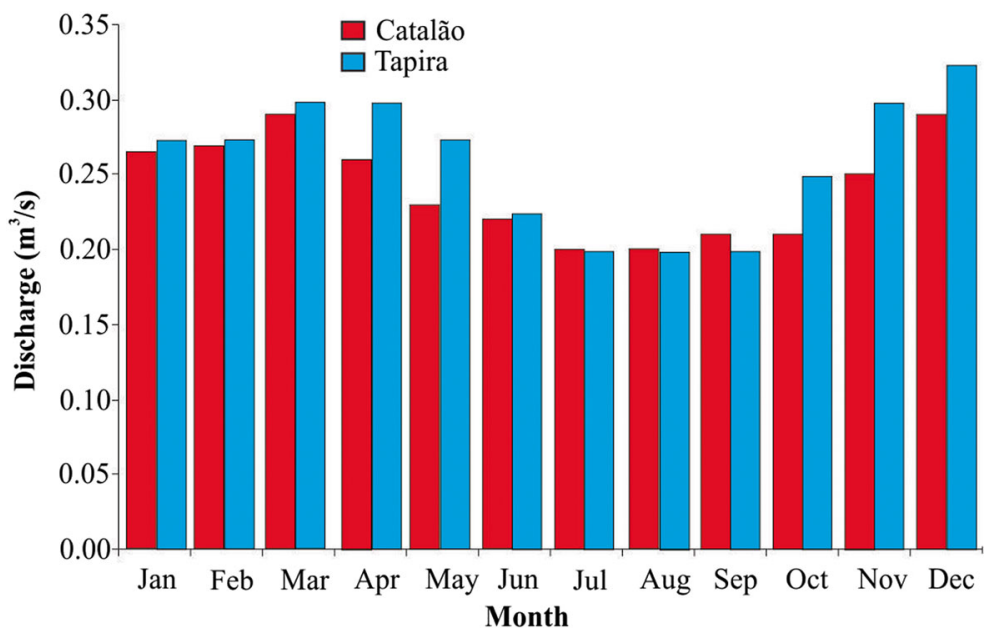


the volume weighted average (VWA) concentrations of elements and compounds using Eq. 1:

$\mathrm{VWA}=\frac{\sum_{i=1}^{n} C_{i} \cdot V_{i}}{\sum_{i=1}^{n} V_{i}}$

Where

VWA weighted average of element or compound (mg/L)

$C_{i} \quad$ concentration of element or compound in the $i$ th sample $(\mathrm{mg} / \mathrm{L})$

$V_{i} \quad$ total volume of rain during the event preceding the $i$ th sample collection (mm).

\subsection{Chemical Analysis}

The electrical conductivity (measured in $\mu \mathrm{S} / \mathrm{cm}$ ) and $\mathrm{pH}$ of each sample were measured in the field by potentiometric methods. The combined electrode was calibrated using the following high purity standards at $\mathrm{pH} 4.00$ (4.00 \pm 0.01 at $\left.25 \pm 0.2^{\circ} \mathrm{C}\right)$ and $7.00\left(7.00 \pm 0.01\right.$ at $\left.25 \pm 0.2^{\circ} \mathrm{C}\right)$. The conductivity meter was calibrated using a $1.0 \mathrm{mmol} / \mathrm{L}$ $\mathrm{KCl}$ solution, which corresponds to $147 \mu \mathrm{S} / \mathrm{cm}$ at $25^{\circ} \mathrm{C}$.

All rainwater samples were stored in polyethylene bottles and filtered using Millipore membranes, with a $0.45 \mu \mathrm{m}$ pore diameter size on the day of collection. Samples were analysed for alkalinity as well as the concentrations of chloride, sulphate, phosphate and nitrate. In another bottle, the rainwater samples were first filtered through the same membrane and conserved with $\mathrm{HNO}_{3}(\mathrm{pH}>2)$ in order to quantify the content of sodium, potassium, calcium and magnesium. Alkalinity was determined by titration with $0.01 \mathrm{~N}$ sulphuric acid at a concentration between 1 and $500 \pm 0.2 \mathrm{mg} / \mathrm{L}$. The concentration of sulphate was determined by the turbidimetric method to be from 0.1 to $70 \pm 0.6 \mathrm{mg} / \mathrm{L}$ sulphate. Phosphate concentrations between 0.02 and $2.5 \pm$ $0.01 \mathrm{mg} / \mathrm{L}$ were measured using the ascorbic acid method. Nitrate concentrations between 0.1 and $10 \pm 0.3 \mathrm{mg} /$ $\mathrm{L}$ were measured using the cadmium reduction method. Sodium, potassium, calcium and magnesium were quantified by atomic absorption spectrometry (AASVarian240-FS), with the following detection limits: $0.05 \mathrm{mg} / \mathrm{L}$ for $\mathrm{Ca}^{2+}, 0.02 \mathrm{mg} / \mathrm{L}$ for $\mathrm{Na}^{+}$and $\mathrm{K}^{+}$, and $0.01 \mathrm{mg} / \mathrm{L}$ for $\mathrm{Mg}^{2+}$. Chloride and fluorine concentrations between 0.01 and $10 \pm 0.01 \mathrm{mg} / \mathrm{L}$ were determined using the potentiometric method.

\subsection{Validation of Results and Statistical Analysis}

The quality of the data was verified by comparing the measured conductivity of each sample to that calculated based on its ionic mass balance. The mass balance $(\Delta$ Ion) of each sample was calculated using Eq. 2, and the conductivity using Eq. 3.

$$
\begin{aligned}
& \Delta \operatorname{Ion}(\%)=\frac{\left[\left(\sum_{\text {cations }}-\sum_{\text {anions }} .100\right)\right.}{\left(\sum_{\text {cations }}+\sum_{\text {anions }}\right)} \\
& k=\Sigma c_{i} \cdot \Lambda_{i}^{o} \\
& \quad \text { Where }
\end{aligned}
$$

$$
\begin{array}{ll}
\Sigma_{\text {cations }} & {\left[\mathrm{H}^{+}\right]+\left[\mathrm{Ca}^{2+}\right]+\left[\mathrm{Na}^{+}\right]+\left[\mathrm{Mg}^{2+}\right]+\left[\mathrm{K}^{+}\right]} \\
\Sigma_{\text {anions }} & {\left[\mathrm{HCO}_{3}{ }^{-}\right]+\left[\mathrm{Cl}^{-}\right]+\left[\mathrm{F}^{-}\right]+\left[\mathrm{PO}_{4}{ }^{3-}\right]+\left[\mathrm{NO}_{3}{ }^{-}\right]+} \\
& {\left[\mathrm{SO}_{4}{ }^{2-}\right]} \\
k & \text { calculated conductivity }(\mu \mathrm{S} / \mathrm{cm}) \\
c_{i} & \text { ionic concentration of the } i \text { th ion }(\mathrm{mmol} / \mathrm{L}) \\
\Lambda_{i}{ }^{o} & \text { molar ionic conductance of the } i \text { th ion }\left(\mathrm{S} / \mathrm{cm}^{2} /\right. \\
& \text { mol) in an infinite dilution at } 25^{\circ} \mathrm{C} .
\end{array}
$$

From the 40 total precipitation events measured at each sampling site, just two events showed anionic balance greater than $25 \%$. These events were discarded, according to the criterion for samples with ionic strength greater than $100 \mu \mathrm{eq} / \mathrm{L}$ suggested by Mosello et al. (1996). All remaining samples with measured conductivity less than $30 \mu \mathrm{S} / \mathrm{cm}$ had less than a $50 \%$ difference between their measured and calculated conductivities and thus were not rejected (Migliavacca et al. 2004). The linear regressions between the sums of cations and anions and calculated and measured conductivity show good correlations ( $r=0.92$ and 0.95 , with $P \leq 0.01$, respectively), indicating that the majority of ions have been measured accurately and that satisfactory corrections were made.

\section{Results and Discussion}

\section{$4.1 \mathrm{pH}$ and Electrical Conductivity Variation}

Figure 4 shows a histogram of the frequency distribution of $\mathrm{pH}$ and electrical conductivity measured in the 

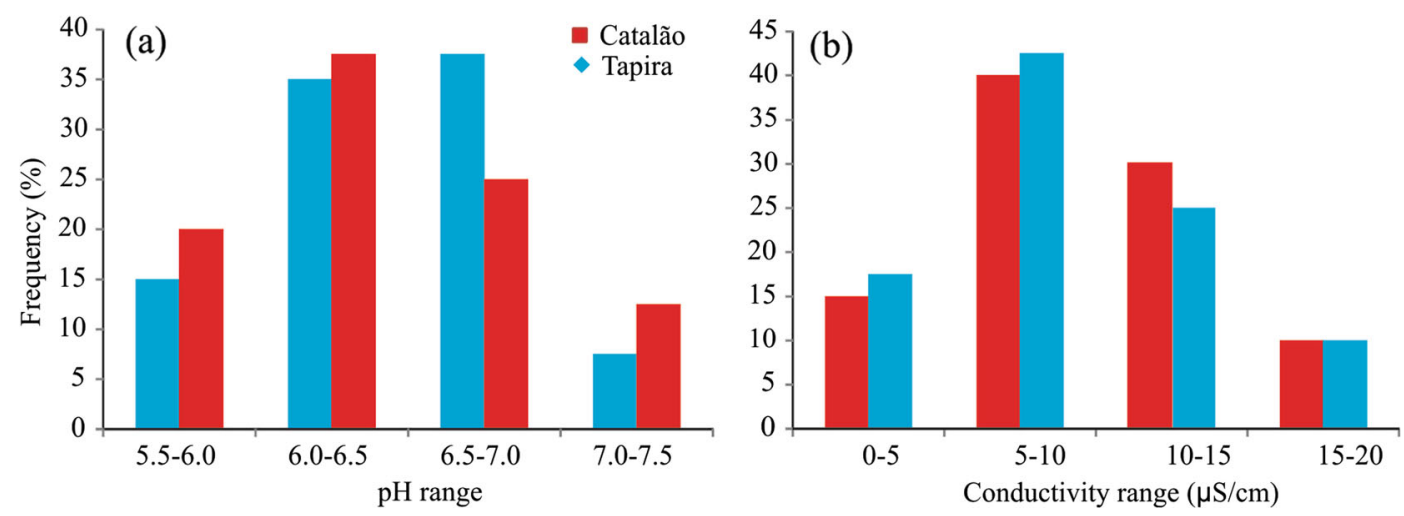

Fig. 4 Histogram of the frequency distribution of $\mathrm{pH}$ and electrical conductivity

precipitation samples in this work. The $\mathrm{pH}$ and electrical conductivity measurements did not vary significantly between sampling locations. The measured electrical conductivity was nearly constant throughout the year, with a VWA of $10.05 \mu \mathrm{S} / \mathrm{cm}$ in Catalão and $9.51 \mu \mathrm{S} / \mathrm{cm}$ in Tapira, thus indicating relatively low values of electrical conductivity in both study areas. Greater VWA was obtained during dry periods $(12.43 \mu \mathrm{S} / \mathrm{cm}$ for Catalão and $11.34 \mu \mathrm{S} / \mathrm{cm}$ for Tapira) than during wet periods $(8.23 \mu \mathrm{S} / \mathrm{cm}$ for Catalão and $7.98 \mu \mathrm{S} / \mathrm{cm}$ for Tapira). The majority of samples had electrical conductivity between 5 and $10 \mu \mathrm{S} / \mathrm{cm}$, followed by values between 10 and $15 \mu \mathrm{S} / \mathrm{cm}, 5$ and $10 \mu \mathrm{S} / \mathrm{cm}$ and 15 and $20 \mu \mathrm{S} / \mathrm{cm}$.

The $\mathrm{pH}$ values of the samples collected in both areas vary between 5.60 and 7.20 , with the greatest values obtained during the dry period (6.90 for Catalão and 6.80 for Tapira). The VWA calculated for $\mathrm{pH}$ from the VWA concentrations of $\mathrm{H}^{+}$were 6.50 for Catalão and 6.34 for Tapira, indicating a free acidity of $0.31 \mu \mathrm{eq} / \mathrm{L}$ in Catalão and $0.46 \mu \mathrm{eq} / \mathrm{L}$ in Tapira. 'Clean' rainwater has a $\mathrm{pH}$ of 5.6, resulting from the partial solubilisation of carbon dioxide $\left(\mathrm{CO}_{2}\right)$ to form carbonic acid $\left(\mathrm{H}_{2} \mathrm{CO}_{3}\right)$. However, the lower limit for rainwater acidified by natural processes is 5.0 (Galloway et al. 1982). No samples from either study area had $\mathrm{pH}$ values lower than 5.0, suggesting that none of these samples could be characterised as acid precipitation. More than $80 \%$ of the total precipitation events sampled in the study areas had basic $\mathrm{pH}(6.0-7.5)$.

\subsection{Chemical Composition and Marine Contribution}

Table 1 presents the minimum and maximum values of the chemical parameters of rainwater measured during the sampling period as well as the volume average weighted (VWA) values measured during wet and dry periods. Because storms influence the chemical composition of rainwater (Moreira-Nordemann et al. 1997), the VWA was utilised in calculations and the following discussion. In this work, the wet period is defined as the period from October to March and the dry period is defined as the period from April to September.

The measured ionic concentrations are highly variable (Fig. 5), with $\mathrm{Ca}^{2+}, \mathrm{Mg}^{2+}$ and $\mathrm{PO}_{4}{ }^{3-}$ ions showing the greatest variability in both study areas. The VWA concentrations indicated that $\mathrm{Ca}^{2+}$ (53 and $45 \%$ of the total cation sum for Catalão and Tapira, respectively) and $\mathrm{HCO}_{3}{ }^{-}$(88 \% of the total anion sum in both areas) are the most abundant ions in the rainwater evaluated in this study. VWA concentrations also showed the following tendency for ion concentrations (measured in $\mu \mathrm{eq} / \mathrm{L}$ ) in both study areas: $\mathrm{Ca}^{2+}>\mathrm{Na}^{+}>\mathrm{Mg}^{2+}>\mathrm{K}^{+}$for cations and $\mathrm{HCO}_{3}{ }^{-}>\mathrm{NO}_{3}{ }^{-}>\mathrm{SO}_{4}{ }^{2-}>\mathrm{PO}_{4}{ }^{3-}>\mathrm{F}^{-}>\mathrm{Cl}^{-}$for anions. The highest concentrations of all elements and compounds occurred during the dry period (April to September). This is to be expected due to higher concentrations of particulate matter in suspension in the atmosphere during the dry period, resulting in the higher concentration of elements and compounds in precipitation (Al-Momani et al. 1995; Hontoria et al. 2003; Migliavacca et al. 2005).

Although the ammonium ion $\left(\mathrm{NH}_{4}{ }^{+}\right)$is not included, Table 1 shows that, based on the VWA concentrations, the sums of cations and of anions analysed in rainwater samples were 157.70 and $155.12 \mu \mathrm{eq} / \mathrm{L}$ in Catalão and 163.05 and $155.26 \mu \mathrm{eq} / \mathrm{L}$ in Tapira. The sum of cations was greater than the sum of anions in both areas, as has been observed in other areas when only inorganic ions were analysed (Galloway et al. 1982; Moreira- 
Table 1 Rainwater chemical composition in Catalão and Tapira phosphate mining $(n=38$ in each sampling site)
${ }^{\mathrm{a}}$ Volume weighted average for 2007

${ }^{\mathrm{b}}$ Volume weighted average for the dry period

${ }^{\mathrm{c}}$ Volume weighted average for the rainy period

\begin{tabular}{|c|c|c|c|c|c|c|}
\hline Parameter & $\mathrm{VWA}^{\mathrm{a}}$ & Minimum & Maximum & $\begin{array}{l}\text { Dry period }^{b} \\
(\mathrm{mg} / \mathrm{L})\end{array}$ & Wet period ${ }^{\mathrm{c}}$ & $\begin{array}{l}\mathrm{VWA}^{\mathrm{a}} \\
(\mu \mathrm{eq} / \mathrm{L})\end{array}$ \\
\hline \multicolumn{7}{|l|}{ Catalão } \\
\hline $\mathrm{H}^{+}$ & - & - & - & - & - & 0.31 \\
\hline $\mathrm{Ca}^{2+}$ & 1.66 & 0.30 & 4.20 & 1.75 & 1.61 & 82.92 \\
\hline $\mathrm{Mg}^{2+}$ & 0.27 & 0.10 & 0.70 & 0.28 & 0.26 & 22.04 \\
\hline $\mathrm{Na}^{+}$ & 0.92 & 0.10 & 2.10 & 0.98 & 0.89 & 39.86 \\
\hline $\mathrm{K}^{+}$ & 0.49 & 0.10 & 1.10 & 0.56 & 0.35 & 12.57 \\
\hline $\mathrm{HCO}_{3}^{-}$ & 7.95 & 5.00 & 20.00 & 8.13 & 6.50 & 130.32 \\
\hline $\mathrm{Cl}^{-}$ & 0.04 & 0.02 & 0.06 & 0.04 & 0.04 & 1.03 \\
\hline $\mathrm{F}^{-}$ & 0.08 & 0.06 & 0.59 & 0.14 & 0.06 & 4.21 \\
\hline $\mathrm{PO}_{4}{ }^{3-}$ & 0.16 & 0.04 & 0.27 & 0.24 & 0.13 & 5.00 \\
\hline $\mathrm{SO}_{4}{ }^{2-}$ & 0.35 & 0.12 & 1.00 & 0.50 & 0.13 & 7.29 \\
\hline $\mathrm{NO}_{3}^{-}$ & 0.45 & 0.11 & 0.84 & 0.61 & 0.18 & 7.27 \\
\hline$\Sigma$ of cations & - & - & - & - & - & 157.70 \\
\hline$\Sigma$ of anions & - & - & - & - & - & 155.12 \\
\hline \multicolumn{7}{|l|}{ Tapira } \\
\hline $\mathrm{H}^{+}$ & - & - & - & - & - & 0.46 \\
\hline $\mathrm{Ca}^{2+}$ & 1.46 & 0.90 & 1.90 & 1.70 & 1.39 & 73.00 \\
\hline $\mathrm{Mg}^{2+}$ & 0.36 & 0.10 & 0.70 & 0.63 & 0.28 & 30.00 \\
\hline $\mathrm{Na}^{+}$ & 1.17 & 0.30 & 3.80 & 1.70 & 1.00 & 50.87 \\
\hline $\mathrm{K}^{+}$ & 0.34 & 0.20 & 0.60 & 0.36 & 0.30 & 8.72 \\
\hline $\mathrm{HCO}_{3}{ }^{-}$ & 8.12 & 5.00 & 15.00 & 8.33 & 6.66 & 133.11 \\
\hline $\mathrm{Cl}^{-}$ & 0.04 & 0.03 & 0.08 & 0.05 & 0.03 & 0.34 \\
\hline $\mathrm{F}^{-}$ & 0.06 & 0.05 & 0.46 & 0.13 & 0.04 & 3.16 \\
\hline $\mathrm{PO}_{4}{ }^{3-}$ & 0.16 & 0.03 & 0.55 & 0.18 & 0.16 & 5.00 \\
\hline $\mathrm{SO}_{4}{ }^{2-}$ & 0.33 & 0.15 & 1.00 & 0.47 & 0.14 & 6.77 \\
\hline $\mathrm{NO}_{3}^{-}$ & 0.42 & 0.12 & 0.93 & 0.58 & 0.16 & 6.88 \\
\hline$\Sigma$ of cations & - & - & - & - & - & 163.05 \\
\hline$\Sigma$ of anions & - & - & - & - & - & 155.26 \\
\hline
\end{tabular}

Nordemann et al. 1997; Lara et al. 2001; Conceição and Bonotto 2004; Conceição et al. 2011).

Catalão and Tapira are cities located in the central and southeast regions of Brazil, in the states of Goiás and Minas Gerais, from which the Atlantic Ocean is approximately $800 \mathrm{~km}$ to the East. Thus, the chemical composition of rainwater samples in this study should be less influenced by sea salt than rainwater samples from coastal areas due to the distance of the sampling sites in this study from the sea. This is confirmed by the smaller VWA concentrations of $\mathrm{Na}^{+}, 39.86 \mu \mathrm{eq} / \mathrm{L}$ in Catalão and $50.87 \mu \mathrm{eq} / \mathrm{L}$ in Tapira, measured in this study compared to the values obtained for other Brazilian cities located in the southeast region, such as
$142.2 \mu \mathrm{eq} / \mathrm{L}$ in Ilha Grande, Rio de Janeiro (Souza et al. 2006), $62.6 \mu \mathrm{eq} / \mathrm{L}$ in Niterói, Rio de Janeiro State (Mello 2001) and $82.0 \mu \mathrm{eq} / \mathrm{L}$ in Cubatão, São Paulo (Danelon and Moreira-Nordemann 1991).

Furthermore, the ionic ratios (in $\mu \mathrm{eq} / \mathrm{L}$ ) measured in this work $\left(\mathrm{Ca}^{2+} / \mathrm{Na}^{+}=2.09, \mathrm{Mg}^{2+} / \mathrm{Na}^{+}=0.55, \mathrm{~K}^{+} / \mathrm{Na}^{+}=\right.$ $0.31, \mathrm{Cl}^{-} / \mathrm{Na}^{+}=3.27, \mathrm{SO}_{4}{ }^{2-} / \mathrm{Na}^{+}=0.13$ and $\mathrm{HCO}_{3}{ }^{-}$/ $\mathrm{Na}^{+}=0.03$ in Catalão and $\mathrm{Ca}^{2+} / \mathrm{Na}^{+}=1.46, \mathrm{Mg}^{2+} / \mathrm{Na}^{+}=$ $0.59, \mathrm{~K}^{+} / \mathrm{Na}^{+}=0.17, \mathrm{Cl}^{-} / \mathrm{Na}^{+}=2.62, \mathrm{SO}_{4}{ }^{2-} / \mathrm{Na}^{+}=0.14$ and $\mathrm{HCO}_{3}{ }^{-} / \mathrm{Na}^{+}=0.01$ in Tapira) relative to rainwater collected near the ocean $\left(\mathrm{Ca}^{2+} / \mathrm{Na}^{+}=0.04, \mathrm{Mg}^{2+} / \mathrm{Na}^{+}=\right.$ $0.23, \mathrm{~K}^{+} / \mathrm{Na}^{+}=0.02, \mathrm{Cl}^{-} / \mathrm{Na}^{+}=1.16, \mathrm{SO}_{4}{ }^{2-} / \mathrm{Na}^{+}=0.12$ and $\mathrm{HCO}_{3}{ }^{-} \mathrm{Na}^{+}<0.01$ ) (Wilson 1975) confirm the lack of marine influence. With the same exception, the other 
Fig. 5 Ionic concentrations

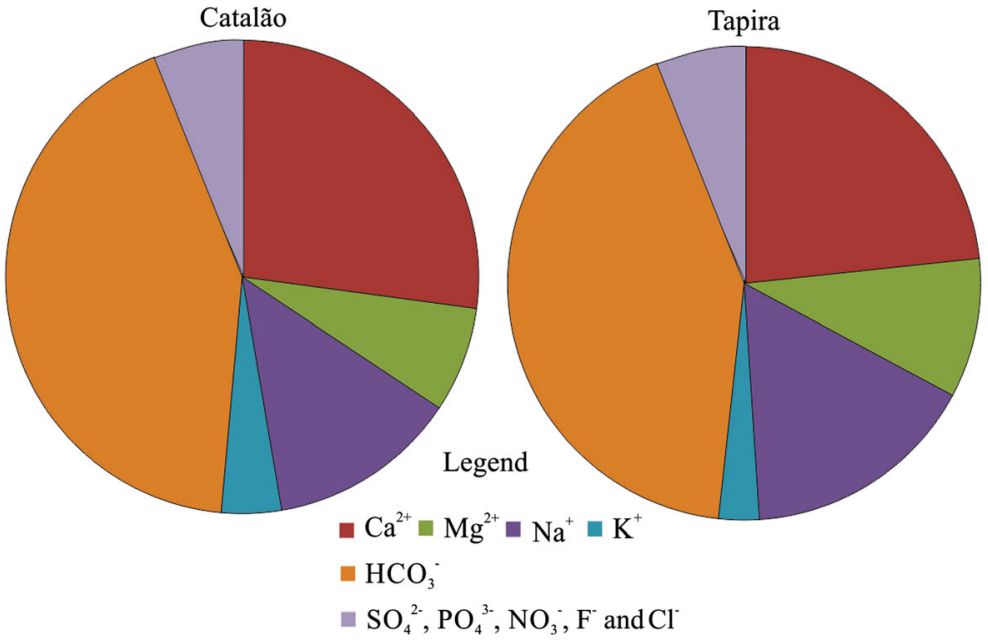

ratios in this study are also greater than the ratios presented by Danelon and Moreira-Nordemann (1991) for Cubatão (SP) and reflect the introduction of terrestrial or anthropic elements and compounds into the rainwaters of Catalão and Tapira. Consequently, the marine contribution to atmospheric precipitation in both areas may be considered negligible.

\subsection{Acidification and Neutralisation Processes}

Anthropogenic sources of atmospheric emissions may be indicated by their $\mathrm{SO}_{4}{ }^{2-} / \mathrm{NO}_{3}{ }^{-}$ratio. In both study areas, the $\mathrm{SO}_{4}{ }^{2-} / \mathrm{NO}_{3}{ }^{-}$ratios were approximately 1.00 , with values lower than those found in other Brazilian sites, such as Porto Alegre (17.2, Luca et al. 1991), São Paulo (1.3, Paiva et al. 1997), the Guaíba Watershed (8.7, Migliavacca et al. 2004), the Candiota area (1.6, Migliavacca et al. 2004), Figueira (5.3, Flues et al. 2002) and Belo Horizonte (2.1, Figueredo 1999). The values observed in the Porto Alegre, Guaíba watershed and Figueira were attributed to the sampling sites being located in industrialised urban areas with heavy traffic. In the areas of Catalão and Tapira, the lower $\mathrm{SO}_{4}{ }^{2-}$ / $\mathrm{NO}_{3}{ }^{-}$ratios might be related to the use of diesel fuel in trucks that are used in the internal and external mining areas.

The presence of $\mathrm{SO}_{4}{ }^{2-}, \mathrm{NO}_{3}{ }^{-}$and organic acids is responsible for acidification potential of rainwater (Kaya and Tuncel 1997), and these compounds can be neutralised by $\mathrm{NH}_{3}$ and $\mathrm{Ca}^{2+}$ (Manahan 1994). Thus, the $\mathrm{pH}$ value in precipitation depends on the relative concentrations of elements and compounds from both of these groups. Statistical tests of linear correlation do not indicate a correlation between the VWA concentrations of $\mathrm{H}^{+}$and any cation or anion, suggesting that the ions analysed in this work are influencing the $\mathrm{pH}$ values of rainwater. Organic acids and ammonia $\left(\mathrm{NH}_{3}\right)$ also have the potential to influence the $\mathrm{pH}$ of rainwater, but were not quantified in this work.

The linear correlation coefficients of the precipitation samples associated with acidification $\left(\mathrm{SO}_{4}{ }^{2-}\right.$ and $\left.\mathrm{NO}_{3}{ }^{-}\right)$ and neutralisation $\left(\mathrm{Ca}^{2+}\right)$ measured in the rainwater in both areas studied ( $r=0.91$ and 0.86 , with $P \leq 0.01$, respectively) suggest that the contribution of other ionic species in the acidification and neutralisation of atmospheric precipitation was not significant. Additionally, the application of linear regression and the high $\mathrm{Ca}^{2+}$ content presented in Table 1 indicates that $\mathrm{Ca}^{2+}$ neutralised the $\mathrm{pH}$ of rainwater in both areas, likely by forming $\mathrm{CaSO}_{4}$ and $\mathrm{Ca}\left(\mathrm{NO}_{3}\right)_{2}$.

\subsection{Statistical Analysis and Annual Atmospheric Deposition}

There were no linear correlations among the other cations or anions measured in the samples in Catalão and Tapira phosphate mining, as shown in Table 2, with the exception of $\mathrm{Ca}^{2+}$ and $\mathrm{Mg}^{2+}, \mathrm{Ca}^{2+}$ and $\mathrm{HCO}_{3}{ }^{-}, \mathrm{Mg}^{2+}$ and $\mathrm{HCO}_{3}{ }^{-}, \mathrm{NO}_{3}{ }^{-}$and $\mathrm{SO}_{4}{ }^{2-}$, and $\mathrm{F}^{-}$and $\mathrm{PO}_{4}{ }^{3-}$ in both study areas. The results of the PCA applied to the original measurements of each parameter in this work, shown in Table 3, indicate that four factor groups explain 87.00 and $89.90 \%$ of the total variance for Catalão and Tapira, respectively. The factor groups of variables are the same for both study areas, while the total variance of factor groups is different between sites. The 
Table 2 Correlation $(P<0.01)$ among all parameters obtained for rainwater in Catalão and Tapira phosphate mining $(n=38$ in each sampling site)

\begin{tabular}{|c|c|c|c|c|c|c|c|c|c|c|c|}
\hline & $\mathrm{H}^{+}$ & $\mathrm{Ca}^{2+}$ & $\mathrm{Mg}^{2+}$ & $\mathrm{Na}^{+}$ & $\mathrm{K}^{+}$ & $\mathrm{HCO}_{3}^{-}$ & $\mathrm{Cl}^{-}$ & $\mathrm{F}^{-}$ & $\mathrm{PO}_{4}^{3-}$ & $\mathrm{SO}_{4}{ }^{2-}$ & $\mathrm{NO}_{3}{ }^{-}$ \\
\hline \multicolumn{12}{|l|}{ Catalão } \\
\hline $\mathrm{H}^{+}$ & 1.00 & & & & & & & & & & \\
\hline $\mathrm{Ca}^{2+}$ & 0.30 & 1.00 & & & & & & & & & \\
\hline $\mathrm{Mg}^{2+}$ & 0.21 & 0.84 & 1.00 & & & & & & & & \\
\hline $\mathrm{Na}^{+}$ & 0.41 & 0.04 & 0.08 & 1.00 & & & & & & & \\
\hline $\mathrm{K}^{+}$ & -0.43 & -0.40 & -0.40 & 0.57 & 1.00 & & & & & & \\
\hline $\mathrm{HCO}_{3}^{-}$ & 0.08 & 0.82 & 0.86 & 0.20 & 0.01 & 1.00 & & & & & \\
\hline $\mathrm{Cl}^{-}$ & 0.54 & 0.37 & 0.10 & -0.11 & 0.54 & 0.39 & 1.00 & & & & \\
\hline $\mathrm{F}^{-}$ & 0.12 & 0.95 & 0.21 & 0.46 & 0.34 & 0.17 & 0.32 & 1.00 & & & \\
\hline $\mathrm{PO}_{4}{ }^{3-}$ & 0.42 & 0.51 & 0.13 & -0.26 & 0.50 & 0.41 & 0.57 & 0.25 & 1.00 & & \\
\hline $\mathrm{SO}_{4}{ }^{2-}$ & 0.49 & 0.39 & 0.47 & 0.37 & 0.31 & -0.08 & 0.370 & 0.36 & 0.05 & 1.00 & \\
\hline $\mathrm{NO}_{3}^{-}$ & -0.29 & -0.28 & -0.36 & -0.33 & 0.42 & 0.13 & 0.327 & 0.44 & 0.41 & 0.914 & 1.00 \\
\hline \multicolumn{12}{|l|}{ Tapira } \\
\hline $\mathrm{H}^{+}$ & 1.00 & & & & & & & & & & \\
\hline $\mathrm{Ca}^{2+}$ & -0.20 & 1.00 & & & & & & & & & \\
\hline $\mathrm{Mg}^{2+}$ & -0.23 & 0.95 & 1.00 & & & & & & & & \\
\hline $\mathrm{Na}^{+}$ & -0.39 & 0.47 & 0.55 & 1.00 & & & & & & & \\
\hline $\mathrm{K}^{+}$ & -0.55 & 0.51 & 0.60 & 0.55 & 1.00 & & & & & & \\
\hline $\mathrm{HCO}_{3}^{-}$ & 0.03 & 0.86 & 0.82 & 0.15 & 0.43 & 1.00 & & & & & \\
\hline $\mathrm{Cl}^{-}$ & 0.16 & 0.55 & 0.41 & 0.14 & 0.52 & 0.47 & 1.00 & & & & \\
\hline $\mathrm{F}^{-}$ & 0.21 & 0.92 & 0.34 & 0.51 & 0.2800 & 0.24 & 0.28 & 1.00 & & & \\
\hline $\mathrm{PO}_{4}^{3-}$ & 0.33 & 0.14 & 0.13 & -0.02 & 0.21 & 0.22 & 0.60 & 0.19 & 1.00 & & \\
\hline $\mathrm{SO}_{4}^{2-}$ & 0.42 & -0.38 & -0.39 & -0.15 & 0.41 & -0.19 & 0.45 & 0.31 & 0.40 & 1.00 & \\
\hline $\mathrm{NO}_{3}^{-}$ & -0.75 & 0.03 & 0.08 & -0.02 & 0.09 & -0.05 & 0.29 & 0.29 & 0.52 & 0.88 & 1.00 \\
\hline
\end{tabular}

The values with strong correlations $(>0.7)$ were in bold

PCA factor groupings are $\mathrm{Ca}^{2+}, \mathrm{Mg}^{2+}$ and $\mathrm{HCO}_{3}{ }^{-}(\mathrm{PCA}$ 1), $\mathrm{NO}_{3}{ }^{-}$and $\mathrm{SO}_{4}{ }^{2-}$ (PCA 2), $\mathrm{K}^{+}$and $\mathrm{Na}^{+}$(PCA 3), and $\mathrm{F}^{-}$and $\mathrm{PO}_{4}{ }^{3-}$ (PCA 4).

In order to improve the PCA results, the annual atmospheric depositions of each ion were calculated by multiplying the VWA concentration of that ion by the total precipitation that occurred between January and December, 2007 (1542 mm in Catalão and $1430 \mathrm{~mm}$ in Tapira). Table 4 presents the annual atmospheric deposition in different Brazilian regions. Although the measurements in Table 4 are from different years, each measurement comprises at least one complete hydrologic cycle. It is worth noting that most of the measurements in Table 4 were conducted only during the wet period. Exceptions are the measurements from Campo Grande, Rio Claro and Ribeirão Preto, where bulk samples were carried out in wet and dry seasons, as in this work. Thus, a comparison among these results was performed to obtain information about the factors that influence rainwater in Catalão and Tapira.

The first factor (PAC1) is associated with $\mathrm{Ca}^{2+}, \mathrm{Mg}^{2+}$ and $\mathrm{HCO}_{3}{ }^{-}$. Apart from Rio Claro and Ribeirão Preto, the greatest annual deposition of $\mathrm{Ca}^{2+}$ and $\mathrm{Mg}^{2+}$ occurred in Catalão and Tapira. Catalão and Tapira have the greater annual deposition of $\mathrm{HCO}_{3}{ }^{-}$than Rio Claro. The high annual deposition of $\mathrm{Ca}^{2+}$ and $\mathrm{Mg}^{2+}$ in Rio Claro and Ribeirão Preto were attributed to intense construction activity in that city (Conceição and Bonotto 2004; Conceição et al. 2015). The correlations between $\mathrm{Ca}^{2+}$ and $\mathrm{HCO}_{3}{ }^{-}, \mathrm{Mg}^{2+}$ and $\mathrm{HCO}_{3}{ }^{-}$and, consequently, $\mathrm{Ca}^{2+}$ and $\mathrm{Mg}^{2+}$ (Table 3) indicate that these elements and compounds observed in this study also likely result from construction activities. One possible explanation for the atmospheric deposition of these cations in both study areas is the dissolution of calcite $\left(\mathrm{CaCO}_{3}+\mathrm{H}^{+} \rightarrow \mathrm{Ca}^{2+}+\mathrm{HCO}_{3}{ }^{-}\right)$dolomite 
Table 3 Principal components analysis (PCA) among all parameters obtained for rainwater in Catalão and Tapira phosphate mining ( $n=38$ in each sampling site)

\begin{tabular}{|c|c|c|c|c|}
\hline Variables & PCA 1 & PCA 2 & PCA 3 & PCA 4 \\
\hline \multicolumn{5}{|l|}{ Catalão } \\
\hline $\mathrm{Ca}^{2+}$ & 0.86 & 0.34 & 0.03 & 0.48 \\
\hline $\mathrm{Mg}^{2+}$ & 0.81 & 0.15 & 0.05 & 0.27 \\
\hline $\mathrm{Na}^{+}$ & 0.14 & -0.42 & 0.87 & 0.12 \\
\hline $\mathrm{K}^{+}$ & -0.09 & 0.29 & 0.76 & 0.08 \\
\hline $\mathrm{HCO}_{3}^{-}$ & 0.82 & -0.21 & 0.28 & -0.02 \\
\hline $\mathrm{Cl}^{-}$ & -0.25 & 0.20 & -0.34 & 0.37 \\
\hline $\mathrm{F}^{-}$ & 0.10 & 0.12 & 0.23 & 0.90 \\
\hline $\mathrm{PO}_{4}^{3-}$ & 0.05 & 0.38 & 0.21 & 0.87 \\
\hline $\mathrm{SO}_{4}^{2-}$ & -0.06 & 0.86 & 0.18 & 0.39 \\
\hline $\mathrm{NO}_{3}^{-}$ & 0.01 & 0.90 & -0.11 & 0.09 \\
\hline Total variance $(\%)$ & 27.90 & 23.40 & 19.00 & 16.70 \\
\hline \multicolumn{5}{|l|}{ Tapira } \\
\hline $\mathrm{Ca}^{2+}$ & 0.90 & 0.12 & 0.07 & 0.51 \\
\hline $\mathrm{Mg}^{2+}$ & 0.91 & 0.19 & 0.11 & 0.24 \\
\hline $\mathrm{Na}^{+}$ & 0.21 & -0.21 & 0.91 & 0.16 \\
\hline $\mathrm{K}^{+}$ & -0.13 & 0.20 & 0.85 & 0.10 \\
\hline $\mathrm{HCO}_{3}^{-}$ & 0.92 & -0.30 & 0.12 & -0.07 \\
\hline $\mathrm{Cl}^{-}$ & -0.30 & 0.16 & -0.27 & 0.22 \\
\hline $\mathrm{F}^{-}$ & 0.24 & 0.17 & 0.20 & 0.94 \\
\hline $\mathrm{PO}_{4}^{3-}$ & 0.12 & 0.30 & 0.19 & 0.93 \\
\hline $\mathrm{SO}_{4}^{2-}$ & -0.10 & 0.92 & 0.11 & 0.13 \\
\hline $\mathrm{NO}_{3}^{-}$ & 0.08 & 0.94 & -0.08 & 0.10 \\
\hline Total variance $(\%)$ & 29.10 & 22.90 & 20.70 & 17.20 \\
\hline
\end{tabular}

The values with strong correlations $(>0.7)$ were in bold

$\left(\mathrm{CaMg}\left(\mathrm{CO}_{3}\right)_{2}+\mathrm{H}^{+} \rightarrow \mathrm{Ca}^{2+}+\mathrm{Mg}^{2+}+\mathrm{HCO}_{3}{ }^{-}\right)$derived from the alkaline-carbonatite carbonates in soil dust. Another possible explanation for these inflows could be the spread of particulate matter in the atmosphere resulting from the largest phosphate mining of alkalinecarbonatite rocks, which plays an important role in controlling the $\mathrm{pH}$ of rainwater in Catalão and Tapira, as previously discussed.

The second factor (PCA 2) consists of $\mathrm{NO}_{3}{ }^{-}$and $\mathrm{SO}_{4}{ }^{2-}$. Among the cities included in Table 4, the greatest annual atmospheric depositions of $\mathrm{NO}_{3}{ }^{-}$and $\mathrm{SO}_{4}{ }^{2-}$ were observed in Rio Claro, Candiota and Cubatão. The $\mathrm{NO}_{3}{ }^{-}$measured in Rio Claro was attributed to intense agricultural activity, including the application of NPK fertilisers (with $\mathrm{N}$ in the form of $\mathrm{NH}_{4} \mathrm{Cl}$ and $\left(\mathrm{NH}_{4}\right)_{2} \mathrm{HPO}_{4}, \mathrm{P}$ in the form of $\left(\mathrm{NH}_{4}\right)_{2} \mathrm{HPO}_{4}$ and $\mathrm{K}$ in the form of $\mathrm{KCl}$ ) (Conceição and Bonotto 2004) and sugar cane burning, which releases $5 \times 10^{4}$ tonnes of $\mathrm{C}$ to the atmosphere from $1 \times 10^{5}$ tonnes of organic matter in the dry period (Lara et al. 2001). Cubatão and Candiota have higher annual atmospheric depositions due to extensive fossil fuel burning by industries (Danelon and Moreira-Nordemann 1991) and thermoelectric plants (Migliavacca et al. 2004), which are the main and permanent $\mathrm{SO}_{\mathrm{x}}$ sources in those regions. This $\mathrm{SO}_{\mathrm{x}}$ is removed from the atmosphere by rainwater in the form of $\mathrm{H}_{2} \mathrm{SO}_{4}$. In Catalão and Tapira, there is no sugar cane burning and the annual atmospheric depositions of these elements and compounds can be attributed to anthropogenic sources as well as to natural sources, such as the oxidation of pyrite to $\mathrm{FeS}_{2}$ in carbonates, producing $\mathrm{SO}_{2}$ or sulphate particles. Emissions from the diesel trucks used in mining facilities and on the roads accessing mining areas contribute elevated levels of $\mathrm{NO}_{3}{ }^{-}$and $\mathrm{SO}_{4}{ }^{2-}$ in annual atmospheric deposition.

The third factor group is composed of $\mathrm{Na}^{+}$and $\mathrm{K}^{+}$. The greatest annual atmospheric deposition of $\mathrm{Na}^{+}$occurred in Cubatão, which is to be expected, as Cubatão is closer to the Atlantic Ocean, a dominant source of $\mathrm{Na}^{+}$ (Moreira-Nordemann and Girard 1996). Among the cities included in Table 4, the greatest annual atmospheric deposition of $\mathrm{K}^{+}$occurred in Candiota due to biomass burning in that area (Migliavacca et al. 2004). The annual atmospheric deposition of these cations must be associated with soil dust derived from the alkalinecarbonatite rocks in Catalão and Tapira areas.

Finally, $\mathrm{PO}_{4}{ }^{3-}$ and $\mathrm{F}^{-}$are associated to the fourth factor group (PCA 4), representing 16.7 and $17.2 \%$ of the total variation in Catalão and Tapira, respectively. The amounts of $\mathrm{PO}_{4}{ }^{3-}$ measured in this work are lower than those measured in Rio Claro, likely due to the use of NPK fertilisers, as previously discussed (Conceição and Bonotto 2004). In both study areas, the mines are mechanised and open to the air. Rock blasting is done mechanically and with explosives. All material removed from the mines is transported in trucks to a crushing plant, where magnetic separation, desliming and flotation are used to separate phosphate ore, which occurs in the form of apatite $\left(\mathrm{Ca}_{5}\left(\mathrm{PO}_{4}\right)_{3} \mathrm{~F}\right)$. Thus, the association between $\mathrm{PO}_{4}{ }^{3-}$ and $\mathrm{F}^{-}$demonstrated by statistical analysis and PCA suggests that the annual atmospheric depositions of this compound and element are related to the spread of particulate matter, particularly apatite, in the atmospheric environment resulting from phosphate mining activities. 
Table 4 Cation and anion annual atmospheric deposition (tonnes $/ \mathrm{km}^{2} /$ year) in some Brazilian regions

\begin{tabular}{|c|c|c|c|c|c|c|c|c|c|c|}
\hline Ion & Manaus $^{\mathrm{a}}$ & Rio Claro ${ }^{\mathrm{b}}$ & Piracicaba $^{c}$ & Campo Grande ${ }^{\mathrm{d}}$ & Cubatão $^{\mathrm{e}}$ & Londrina $^{\mathrm{f}}$ & Candiota $^{\mathrm{g}}$ & Ribeirão Preto ${ }^{\mathrm{h}}$ & Catalão & Tapira \\
\hline $\mathrm{Ca}^{2+}$ & 0.13 & 10.42 & 0.12 & 0.24 & - & - & 2.06 & 5.00 & 2.56 & 2.09 \\
\hline $\mathrm{Mg}^{2+}$ & 0.03 & 1.12 & 0.03 & 0.04 & - & - & 0.34 & 1.00 & 0.42 & 0.51 \\
\hline $\mathrm{Na}^{+}$ & 0.15 & 1.52 & 0.07 & 0.26 & 5.06 & 0.19 & 1.97 & 0.90 & 1.54 & 1.67 \\
\hline $\mathrm{K}^{+}$ & 0.90 & 0.41 & 0.13 & 0.24 & - & 0.04 & 1.20 & 0.60 & 0.76 & 0.49 \\
\hline $\mathrm{HCO}_{3}^{-}$ & - & 2.24 & - & - & - & - & - & 16.40 & 12.26 & 11.61 \\
\hline $\mathrm{Cl}^{-}$ & 0.45 & 3.46 & 0.28 & 1.00 & 12.39 & 0.71 & 3.75 & 0.30 & 0.06 & 0.06 \\
\hline $\mathrm{F}^{-}$ & - & - & - & - & - & - & - & - & 0.12 & 0.09 \\
\hline $\mathrm{PO}_{4}{ }^{3-}$ & $<0.01$ & 0.55 & - & - & - & - & - & 0.10 & 0.25 & 0.23 \\
\hline $\mathrm{SO}_{4}{ }^{2-}$ & 0.26 & 3.46 & 0.99 & 0.48 & 7.54 & 1.07 & 7.97 & 1.90 & 0.39 & 0.47 \\
\hline $\mathrm{NO}_{3}{ }^{-}$ & 0.72 & 7.09 & 1.11 & 0.79 & 1.99 & 1.06 & 4.02 & 1.60 & 0.69 & 0.60 \\
\hline
\end{tabular}

${ }^{a}$ Williams et al. (1997)

${ }^{\mathrm{b}}$ Conceição and Bonotto (2004)

${ }^{\mathrm{c}}$ Lara et al. (2001)

${ }^{\mathrm{d}}$ Moreira-Nordemann et al. (1997)

${ }^{\mathrm{e}}$ Danelon and Moreira-Nordemann (1991)

${ }^{\mathrm{f}}$ Pelicho et al. (2006)

${ }^{\mathrm{g}}$ Migliavacca et al. (2004)

${ }^{\mathrm{h}}$ Conceição et al. 2015

\section{Conclusions}

The results of the analyses of rainwater in the cities of Catalão and Tapira showed a volume weighted average (VWA) $\mathrm{pH}$ of 6.90 and 6.80 , respectively, corresponding to a free acidity of $0.31 \mu \mathrm{eq} / \mathrm{L}$ in Catalão and $0.46 \mu \mathrm{eq} / \mathrm{L}$ in Tapira. In contrast, the VWA values of electrical conductivity were $10.05 \mu \mathrm{S} / \mathrm{cm}$ in Catalão and $9.51 \mu \mathrm{S} / \mathrm{cm}$ in Tapira, and the greatest values were measured during the dry period. The ionic concentrations (in $\mu \mathrm{eq} / \mathrm{L}$ ) decreased in the following order in both study areas: $\mathrm{Ca}^{2+}>\mathrm{Na}^{+}>\mathrm{Mg}^{2+}>\mathrm{K}^{+}$for cations and $\mathrm{HCO}_{3}{ }^{-}>\mathrm{NO}_{3}{ }^{-}>\mathrm{SO}_{4}{ }^{2-}>\mathrm{PO}_{4}{ }^{3-}>\mathrm{Cl}$. The VWA concentrations of $\mathrm{Na}^{+}$were smaller than the values obtained for the coastal regions in southeastern Brazil. The high $\mathrm{Ca}^{2+}$ content neutralises the $\mathrm{pH}$ of rainwater in both study areas, $\mathrm{CaSO}_{4}$ and $\mathrm{Ca}\left(\mathrm{NO}_{3}\right)_{2}$ being the most likely compounds formed during the neutralisation processes. The annual atmospheric deposition of $\mathrm{Ca}^{2+}, \mathrm{Mg}^{2+}$ and $\mathrm{HCO}_{3}{ }^{-}$occur due to the dissolution of calcite $\left(\mathrm{CaCO}_{3}+\mathrm{H}^{+} \rightarrow \mathrm{Ca}^{2+}+\mathrm{HCO}_{3}{ }^{-}\right)$and dolomite $\left(\mathrm{CaMg}\left(\mathrm{CO}_{3}\right)_{2}+\mathrm{H}^{+} \rightarrow \mathrm{Ca}^{2+}+\mathrm{Mg}^{2+}+\mathrm{HCO}_{3}{ }^{-}\right)$in the atmosphere, possibly derived from phosphate mining activities. The annual atmospheric deposition of $\mathrm{NO}_{3}{ }^{-}$and $\mathrm{SO}_{4}{ }^{2-}$ can be attributed to emissions from dieselpowered trucks used in internal and external areas of

mines. Soil dust derived from the magmatic rocks found in Catalão and Tapira is responsible for the annual atmospheric deposition of $\mathrm{Na}^{+}$and $\mathrm{K}^{+}$. The dust from phosphate mining activities, in which apatites are concentrated, may be the main source of the annual atmospheric deposition of $\mathrm{PO}_{4}{ }^{3-}$ and $\mathrm{F}^{-}$. Thus, the present study confirmed that the phosphate mining activities located in the cities Catalão and Tapira are affecting the atmospheric environment, as these anthropogenic sources are responsible for neutralising the rainwater in both areas.

Acknowledgements The authors would like to thank FAPESP (Processes 2005/59203-1, 2006/54884-3, 2006/55477-2 and 2006/61208-4) for the financial support for this research. The authors would also like to thank Fosfertil S.A., currently Vale S.A., for the permission to access the phosphate mining areas for collection and analysis of rainwater in both study areas.

\section{References}

Al-Momani, I. F., Ataman, O. Y., Anwari, A. M., Tuncel, S., Köse, C., \& Tuncel, G. (1995). Chemical composition of precipitation near an industrial area at Izmir, Turkey. Atmospheric Environment, 29, 1131-1143.

Berner, E. K. \& Berner, R. A. (1996). Global environment, water, air and geochemical cycles. Prentice Hall. 
Conceição, F. T., \& Bonotto, D. M. (2004). Weathering rates anthropogenic influences in a sedimentary basin, São Paulo State, Brazil. Applied Geochemistry, 19, 575-591.

Conceição, F. T., \& Bonotto, D. M. (2006). Distribuição de radionuclídeos, metais pesados e flúor nos perfis supérgenos de Tapira (GO) e Catalão (GO). Geochimica Brasiliensis, 20, 175-190.

Conceição, F. T., Sardinha, D. S., Souza, A. D. G., \& Navarro, G. R. B. (2010). Anthropogenic influences on annual flux of cations and anions at Meio Stream basin, São Paulo State, Brazil. Water, Air, and Soil Pollution, 205, 79-91.

Conceição, F. T., Sardinha, D. S., Navarro, G. R. B., Antunes, M. L. P., \& Angelucci, V. A. (2011). Rainwater chemical composition and annual atmospheric deposition at Alto Sorocaba basin. Quimica Nova, 34, 610-616.

Conceição, F. T., Santos, C. M., Sardinha, D. S., Navarro, G. R. B., \& Godoy, L. H. (2015). Chemical weathering rate, denudation rate, and atmospheric and soil $\mathrm{CO}_{2}$ consumption of Paraná flood basalts in São Paulo State, Brazil. Geomorphology, 233, 41-51.

Danelon, O. M., \& Moreira-Nordemann, L. M. (1991). Ocorrência Natural e Antropogênica de $\mathrm{Cl}^{-}, \mathrm{Na}^{+}, \mathrm{NO}_{3}{ }^{-}, \mathrm{NH}_{4}{ }^{+}$e $\mathrm{SO}_{4}{ }^{+}$na Bacia do Rio Quilombo (Cubatão-SP). Revista Brasileira de Geociencias, 21, 96-101.

DNPM-Departamento Nacional de Produção Mineral. (2011). Anuário Mineral Brasileiro 2010. Brasília, DNPM, 35, 871 p.

DNPM - Departamento Nacional de Produção Mineral. (2012). Sumário Mineral 2012. Brasília, DNPM, 32, 136 p.

DNPM - Departamento Nacional de Produção Mineral. (2014). Informe Mineral 1\%2014. Brasília, DNPM, $21 \mathrm{p}$.

Figueredo, D. V. (1999). Influence of calcareous soil particulates on acid rain: Belo Horizonte metropolitan region, Brazil. Ambio, 28, 514-518.

Flues, M., Hamma, P., Lemes, M. J. L., Dantas, E. S. K., \& Fornaro, A. (2002). Evaluation of the rainwater acidity of a rural region due to a coal-fired power plant in Brazil. Atmospheric Environment, 36, 2397-2404.

Fontenele, A. P. G., Pedrotti, J. J., \& Fornaro, A. (2009). Avaliação de metais e íons majoritários em águas de chuva na cidade de São Paulo. Quimica Nova, 32, 839-844.

Fornaro, A., \& Gutz, I. G. R. (2006). Wet deposition and related atmospheric chemistry in the São Paulo metropolis. Part 3: trends in the precipitation chemistry during 1983-2003. Atmospheric Environment, 40, 5893-5901.

Forti, M. C., Moreira-Nordemann, L. M., Andrade, M. F., \& Orsini, C. Q. (1990). Elements in the precipitation of São Paulo city (Brazil). Atmospheric Environment, 24, 355-360.

Galloway, J. N., Likens, G. E., Keene, W. C., \& Miller, J. M. (1982). The composition of precipitation in remote areas of the world. Journal of Geophysical Research, 87, 8771-8786.

Gibson, S. A., Thompson, R. N., Leonardos, O. H., Dickin, A. P., \& Mitchell, J. G. (1995). The Late Cretaceous impact of the Trindade mantle plume - evidence from large-volume, mafic, potassic magmatism is SE Brazil. Journal of Petrology, 36, 189-229.

Gonçalves, F. L. T., Massambani, O., Beheng, K. D., Vautz, W., Schilling, M., Solci, M. C., Rocha, V., \& Klockow, D. (2000). Modelling and measurements of below cloud scavenging processes in the highly industrialized region of Cubatão-Brazil. Atmospheric Environment, 34, 41134120 .
Hontoria, C., Saa, A., Almorox, J., Cuadra, L., Sánchez, A., \& Gascó, J. M. (2003). The chemical composition of precipitation in Madrid. Water, Air, and Soil Pollution, 146, 35-54.

Kaya, G., \& Tuncel, G. (1997). Trace element and major ion composition of wet and dry deposition in Ankara, Turkey. Atmospheric Environment, 31, 3985-3998.

Keene, W. C., Pszenny, A. A. P., Galloway, J. N., \& Hawley, M. E. (1986). Sea-salt corrections and interpretation of constituent rations in marine precipitation. Journal of Geophysical Research, 91, 6647-6658.

Lara, L. B. L. S., Artaxo, P., Martinelli, L. A., Victoria, R. L., Camargo, P. B., Krusche, A., Ayres, G. P., Ferraz, E. S. B., \& Ballester, M. V. (2001). Chemical composition of rainwater and anthropogenic influences in the Piracicaba river basin, southeast Brazil. Atmospheric Environment, 35, 4937-4945.

Leal, T. F. M., Fontenele, P. G., Pedrotti, J. J., \& Fornaro, A. (2004). Composição iônica majoritária de águas de chuva no centro da cidade de São Paulo. Quimica Nova, 27, 855861.

Luca, S. J., Milano, L. B., \& Ide, C. N. (1991). Rain and urban stormwater quality. Water Science and Technology, 23, 133140.

Manahan, S. E. (1994). Environmental chemistry (6th ed.). Florida, USA: CRC Press.

Mello, W. Z. (2001). Precipitation chemistry in the coast of the Metropolitan Region of Rio de Janeiro, Brazil. Environmental Pollution, 114, 235-242.

Mello, W. Z., \& De Almeida, M. (2004). Rainwater chemistry at the summit and southern flank of the Itatiaia massif, Southeastern Brazil. Environmental Pollution, 129, 63-68.

Migliavacca, D., Teixeira, E. C., Pires, M., \& Fachel, J. (2004). Study of chemical elements in atmospheric precipitation in South Brazil. Atmospheric Environment, 38, 1641-1656.

Migliavacca, D., Teixeira, E. C., Wiegand, F., Machado, A. C. M., \& Sanchez, J. (2005). Atmospheric precipitation and chemical composition of an urban site, Guaíba hydrographic basin, Brazil. Atmospheric Environment, 39, 1829-1844.

Molinaroli, E., Pistolato, M., Rampazzo, G., \& Guerzoni, S. (1999). Geochemistry of natural and anthropogenic fall-out (aerosol and precipitation) collected from the NW Mediterranean: two different multivariate statistical approaches. Applied Geochemistry, 14, 423-432.

Moreira-Nordemann, L. M. \& Girard, P. (1996). Precipitação úmida comparativa em duas cidades brasileira. Anais do VII Congresso Argentino de Meteorologia.

Moreira-Nordemann, L. M., Girard, P., \& Ré Poppi, N. (1997). Química da precipitação atmosférica na cidade de Campo Grande (MS). Revista Brasileira de Geofisica, 15, 36-42.

Mosello, R., Bianchi, M., Geiss, H., Marchetto, A., Serrini, G., Serini Lanza, G., Tartari, G.A., Muntau, H. (1996). AQUACON-MedBas Subproject No. 6: acid rain analysis. Environment Institute: Luxembourg.

Négrel, P., \& Roy, S. (1998). Chemistry of rainwater in the Massif Central (France): a strontium isotope and major element study. Applied Geochemistry, 13, 941-952.

Oliveira, S. M. B., \& Imbernon, R. A. L. (1998). Weathering alteration and related REE concentration in the Catalão I carbonatite complex, central Brazil. Journal of South American Earth Sciences, 11, 379-388.

Paiva, R. P., Pires, M. A. F., Munita, C. S., Andrade, M. F., Gonçalves, F. L. T., \& Massambani, O. (1997). A preliminary 
study of the anthropogenic contribution to São Paulo rainfall. Fresenius Environmental Bulletin, 6, 508-513.

Pelicho, A. F., Martins, L. D., Nomi, S. N., \& Solci, M. C. (2006). Integrated and sequential bulk and wet-only samplings of atmospheric precipitation in Londrina, South Brazil (1998-2002). Atmospheric Environment, 40, 6827-6835.

Rocha, F. R., da Silva, J. A. F., Lago, C. L., Fornaro, A., \& Gutz, I. G. R. (2003). Wet deposition and related atmospheric chemistry in the São Paulo metropolis, Brazil. Part 1: major inorganic ions in rainwater as evaluated by capillary electrophoresis with contactless conductivity detection. Atmospheric Environment, 37, 105-115.
Saueia, C. H. R., \& Mazzilli, B. P. (2006). Distribution of natural radionuclides in the production and use of phosphate fertilizers in Brazil. Journal of Environmental Radioactivity, 89, 229-239.

Souza, P. A., Mello, W. Z., Maldonado, J., \& Evangelista, H. (2006). Composição química da chuva e aporte atmosférico na Ilha Grande, RJ. Quimica Nova, 29, 471-476.

Williams, R. M. \& Fisher, T. M. (1997) Chemical composition and deposition of rain in the Central Amazon, Brazil. Atmospheric Environmental, 31, 207-217.

Wilson, T. R. S. (1975). Salinity and the major elements of sea water. In J. P. Riley \& G. Skirrow (Eds.), Chemical oceanography (2nd ed.). Orlando, Florida, USA: Academic. 